\title{
MODELLING OF TRANSITION TO ADULTHOOD FOR ADOLESCENTS AT SOCIAL RISK
}

\author{
Ingrida Baranauskienė \\ Milda Krauzienè \\ Rita Virbalienè \\ Šiauliai university, Lithuania
}

\begin{abstract}
The transition from the education system to the adult labor market system is mediated by interacting subjective and structural factors specific to each country including its educational system structure and organization, social and cultural context, demographic factors, labor market and role of state in shaping labor supply and demand. The article reviews the theoretical analysis of transition to adulthood of adolescents at social risk attending day care center. Adolescents at social risk attending day care center have not enough social skills. According to the study, social risk adolescents attending day care center lack of self-awareness skills at most. Essay analysis revealed that these teens are unable to organize their nutrition properly, purchase foods themselves and rationally manage their money. After applying the social skills program the most obvious change in social risk teenagers attending day care center was better self-knowledge skills. These adolescents gained knowledge of healthy nutrition. They would consider before buying certain goods is it necessary. In their essay about personal finance savings social risk adolescents in day care center expressed a more rational approach to money.
\end{abstract}

Keywords: day-care center, the transition to adult life, social skills, social risk teenagers.

\section{Introduction}

Teen is one of the most sensitive and vulnerable groups in society, since this age period they are confronted not only with physiological changes in the body, but there is a problem of self-realization and looking for personal identity. According to Gailius and others (2013), identity search is often associated with internal and external tensions, otherwise referred to as the state of crisis phenomena, and often filled with conflicts. Psychosocial development of personality is complicated by negative experiences, such as cognitive and emotional deprivation, insecurity and feelings of rejection in the family, outbreaks of physical and psychological violence in the family and in the environment, failures of learning and interaction with peers and teachers school and so on. These experiences certainly change the normal psychosocial development of person cycle and qualitative parameters (Bakutytè, Geležinienè et al. 2013). Obviously, due to the lack of social skills the transition to adult life period becomes very difficult for adolescents at social risk because they do not have enough knowledge about the self-life characteristics. Most social-risk adolescents fail to manage social situations, constructively deal with conflicts 
and problems that arise. It should be noted that the transition from teen school age to adult life is determined by many factors and their interactions. So disturbed functioning of one link ruins the whole system performance. In this case, the social-risk adolescents do not have suitable example in their families, i.e. at the institute of primary socialization. For this reason, social risk teens are usually picked up by the in appropriate behaviors. It is due to interruption of the process of socialization they get into the social risk group. Smart and others (2008) (cit. Legkauskas 2013) suggests that adolescents with a good relationship with their parents are less likely to use drugs, learn better, are more independent and less experienced social and psychological problems. The authors stress that they have better social skills and are more optimistic about the future.

Looking for solutions of social problems of children at risk important role goes to non-governmental organizations that provide integrated social services and thus address not only the child problems but those of the whole family (Kvedaravičiūtè, 2007). According Griškutè and Masiliauskienè (2010), one of the institutional aid forms for social risk families and children living in is the children day care centers. It is assumed that attending children day-care centers promotes a healthy and productive personal development. These centers provide comprehensive assistance satisfying the children needs which are not met by their biological parents. In addition, it is necessary to mention that day care centers for children of problem families help to normalize disturbed relationships with the social environment. In order to ensure for teenagers from disadvantaged families the successful adaptation and integration in society, more attention should be paid to the problems of preparation to an independent life. Social skills training and preparation for independent living should become a priority for the public and attract considerable attention to the development of educational programs and activities for the organization of training to develop these skills, not only in the context of formal education, but also in non-formal education. Developing of the skills allows avoid of the various deviant behaviors, to change inappropriate behavior towards appropriate, to prepare for independent living (Vosylienè, 2009).

Scientific research and practical relevance. Recently, a number of issues on social skills examination have been researched. Vaitiekienè (2013) analyzed the social skills of children attending day service activities. Jančauskyte, Širiakovienè, Plaušinaitienè (2013) studied the social skills development opportunities for children from disadvantaged families using art activities in children day care centers. Malinauskas (2011) in his study evaluated the social skills of children at risk. Raudeliūnaite (2007) revealed the peculiarities of expression of social skills of visually impaired teenagers studying in special and mainstream schools and the pedagogical assumptions of their education. Webster, Low, Siller and Hackett (2013), examined the influence of father's role in the child's social skills development process. Erozkan (2013), focused on communication skills arguing that communication is a key element in the 
process of human development, which helps to make contact with others. However, there is still a lack of comprehensive research of the peculiarities of social risk teens transition from school age to adult life process. One of the first who began to examine aspects of the process were Hallahan and Kauffman (2003), but most of their studies examined the difficulties young people with disabilities experienced during the transition time. Bronte-Tinkew and others (2005) in the Report on transitory elements identified key areas related to the transition to adulthood. These are the independence, shaping the household and family, health area, preparation for work, entrepreneurial skills, civic participation, social and emotional development, social relationships. Brazienè and Mikutavičienè (2013) analyzed the Lithuanian young people's transition from education system to the labor market from the employment policies point of view.

The object of research: the peculiarities of transition from school age to adulthood of social risk children attending day-care center.

The research goal: to present the characteristics of transition from school age to adult life of social-risk teenagers attending day care center, by developing their social skills.

Methods of research: Theoretical: the scientific literature analysis; Empirical: action research. Data processing method: content analysis. The graphical representation of the survey data conducted using Excel XP program.

The research instrument. Social skills training program. Topics selected on the basis of lessons from practical work experience of one article's author and of Bart, KH Schindler (2001) Social behavior guidance.

Problematic questions. Do social risk adolescents attending day care centre experience more difficulties during transition from school age to adulthood because of lack of social skills? Which skills need to be developed to have influence on successful transition to adulthood of adolescents at social risk? The article is based on the pragmatism philosophy ideas. According to this concept the development is oriented towards life problem solving via the activities and the practical experience is particularly stressed as the background of education. Thus, the transition of social risk adolescents to adulthood could be based on ideas of pragmatism philosophy as the only development of practical skills would allow for those adolescents to become suitable members of changing society. The practical knowledge acquired could be brought by the adolescents to daily life. Dewey (1998) states that pupils shall be able adequately solve arising problems which often are integral part of the life of adolescents at social risk attending the day care centre.

The representative of modern pragmatism Rorty (1999) stresses the importance of socialization in the life of the person. He states that at first, the process of socialization is related with the truth as adequacy of public norms and conventions. According to Rorty (1999), person until 18 or even 19 years acquires knowledge and is socialized. During the process of socialization the 
individual by interacting with environment takes certain social experience, values which form the background for the shaping of main attitudes.

\section{The methodology and organization of the research}

The empyrical research has been performed using the qualitative approach. This approach is closer to the objectives of the research as it provides the possibility to investigate the particularities of transition from school age to adult life of social risk adolescents without giving too much importance to the quantitative indicators. Kardelis (2002) describes the qualitative research as the systematic non-structured study of case or group of individuals, of situation or event in the natural environment with the view to understand the investigated phenomena and provide the interpretation and holistic explanation of them. Applying only quantitative research makes it more difficult to examine everything what took place during the planned and organized exercise of development of social abilities (Vyšniauskytè - Rimkienè, 2008).

The action research is selected for this study. According to Charles (1999), action research is related with the creation of new plan and procedure and verification. Action reserach was done using the Social skills development program adapted by one of the authors which helps prepare properly for the transition from school age to adult life and for the independent life.

Preparation for independent life should be comprehensive and for this both practical as well as emotional and intepersonal communication skills are important (Independent living minimum standards recommended for children in foster care, 2004). For this reason, the concept of social skills is used as broath as possible in order to include not only emotional and interpersonal skills but also those skills which are important for daily life. According to Vaitiekiene (2013), social skills in narrow sense are those which help people easier adapt and communicate with each other. Social skills in broather sense mean the ability to acquire profession, find a job, deal with money, buy reasonably only what is necessary, maintain your own environment, keep clean facilities, follow norms of hygiene. Therefore in the first part of Social skills development program the interpersonal communication skills such as self-knowledge, management of anger etc.are stressed. Second part is focused on daily life skills such as personal financial savings, preparation of food, personal hygiene etc. The program is composed from 12 exercises: 1) Presentation of the program, knowing each other, building up of agreements; 2) Expression of feelings, anger management; 3) Self-knowledge; 4) The world where I would like to live; 5) Compliments and saying of them; 6) Body language; 7) A healthy diet; 8) Food preparation; 9) Shopping at the grocery store; 10) The personal hygiene; 11) Personal Finance; 12) Lessons learned, summary of expressing feelings. Central method of research data collection method is the analysis of essays of social risk teenagers attending day care center. Essays topics are following: 
„How do I express my feelings and manage anger?” „How well you know yourself?”, „The world in which I would like to live”, „How I say compliments and respond to them?”, ,Nonverbal language in my life”, ,My eating habits”, „Food preparation”, „Shopping at the grocery store”, „How do I care my hygiene?” „My personal finances”.

The obtained material processed using content analysis method that was used according to Straus, Korbin methodological justification (Страусc, Корбин, 2001). Data categorized by semantic links and graphically depicted using Microsoft Office Excel.

The action research have been applied, which according to O'Brien (1998) is used in real life, but not for unreal situations, since the main focus is on solving the real problems and on the holistic approach, because it is more focused on problem-solving, and not only to data collection and analysis. The study included classes and observations of social risk teenagers attending day care center behavior and the environment around them. „As the action research is done in the real context and involves close and open communication between related persons, the researchers should pay special attention to the ethical aspects" (O'Brien, 1998). Therefore, while performing action research in the day center, social risk adolescents, in particular, have been informed about the exercises, which would be organized. The study participants must know what will be the study and its tasks. Writing essays was guided by ethical principles such as confidentiality, democracy, fairness and privacy. The research participants also agreed to participate voluntarily in the study performed. Efforts have been made to highlight the desire of positivity and changes at the end of exercises.

\section{Operational phases of the study}

I. The assessment of social and life skills of social risk teens at the beginning of the program.

II. Evaluation of the effectiveness of the program at the end of the program. III. Applying the program on social risk adolescents.

Phase I. The first step was to figure out the social risk adolescent social skills level. Consequently, pupils were asked to write essays on the following topics: „How I express feelings and manage my anger?” „Do you know yourself well?", ,The world in which I would like to live”, „HowI say” compliments and respond to them?” „Nonverbal language in my life”, ,My eating habits”, „Food preparation”, „Shopping at the grocery store”, „How do I care about my hygiene?" „My personal finances”. Essays topics coincided with the topics to be covered during the classes foreseen in order to assess the social and life skills development after completion.

Phase II. At this stage, it was planned 12 sessions (the introductory part, 5 classes for the social skills, 5 classes for life skills, summary of sessions). Social 
and life skills education was organized on average twice a week. According Vyšniauskytè - Rimkienès and Liobikienè (2012), social skills training sessions recommended to be organized at least once a week, and the optimal solution is two times per week. The exercise time is 1.5 hours. Since for some of the topics tackled was not enough time for the pursuit of one, they were divided into two parts. The first part presents the theoretical part, the second covers the practical. Each session began with a introductory theoretical part, then led a practical exercise, and the session ends with a summary of the discussion and the expression of feelings of participants. A lot of attention is paid to pupils' needs and purposeful time spending.

Sessions were led by the Social skills development program based on Snir and Malinauskas (2006) practical exercises that develop social skills, as well as on Orphans and children without parental care independent living skills training program implementation recommendations (2007), on elaborated by Bučinskienè, Baranauskienè, Butvilienè, Grèbliūnienè, Kasperavičienès, Lapienis (2001) Chef's of cooking guide, and Bart and Shindler (2001) advices in the Social behavior guide for development oflife skills. During this phase, so called „Spiral” approach was used, i. e. constant checking up how adolescents perceive training material and how they accept it.

Phase III. This is a very important step, as it provides the opportunity to evaluate the effectiveness of the program. In order to assess activities performed and social skills training program influence on social risk adolescents, the learners were again asked to write essays on topics already mentioned above. During this phase, experience is summarized, which makes it possible to adjust the program and to develop a project.

Sample and local characteristics. The study was conducted in children and youth day center in Kelme, from December, 2013 until February, 2014. The convenience sample was used in the study. The participants were 12 teenagers at social risk attending the day care center. Since all the participants of the research were minors (aged 13 to 17 years), the study was carried out having social risk teenagers attending day care center, their parents or guardian's permission. In the study, data was collected on the demographic situation of the respondents (i.e, gender, age). From the 12 respondents to the survey 8 were girls and 4 were guys.

\section{The analysis of essays written by social risk teenagers attending day care centers before classes}

In order to structure the responses of social risk adolescents attending day care centre about expressing feelings and anger management six categories were created: 1) Adequate anger management techniques; 2) The positive expression of feelings; 3) Lack of knowledge as to express feelings; 4) The expression of feelings according to the situation; 5) The physical expression of anger; 
6) Bullying as reason to be angry. We can assume that these are only theoretical answers, because in reality the majority of adolescents belonging to social risk group are not able to properly express their feelings and manage anger but. They lack the skills that help manage anger and express other feelings, positive or negative feelings expression depends on the current situation, being unable to properly manage and express anger in words, they do it by using force. Bullying prevails among the disadvantaged teenagers and that cause negative emotions, including anger.

Peforming the analysis of social skills of social risk teenagers attending day care center there was extremely important to find out how these teens know yourself. Proper self-knowledge enables better understanding and feelings of others, developing empathy. Analysis of essays allowed to distinguish three categories regard the issue of self-knowledge. These are: 1) the lack of selfknowledge; 2) proper self-knowledge; 3) the effort to get to know yourself better. From the analysis of the respondent asnwers it can be assumed that the respondents lack of self-knowledge skills.

Respondents were asked to write an essay on topic ,The world in which I would like to live." Four categories were distinguished: 1) expectations related to spiritual values; 2) expressing of unrealistic wishes; 3) emphasis on material things; 4) the need for a sense of security. From the analysis of the respondent answers it can be assumed that the respondents lack of self-awareness skills. Respondents would like to live in a world without anger, but they have unrealistic desires and fantasies associated with impractical things and their dream world is related only with material things. Not everyone feels safe.

In order to find out the peculiarities of communication skills of social risk teenagers attending day care center, they were asked to write an essay on topic „How I say compliments and respond to them?" Four categories wre distinguished: 1) Adequate reaction to the compliment heard; 2) A positive effect of compliments; 3) Telling often comliments to others; 4) Not willing to tell a compliment. From the analysis of the answers it can be said that the respondents properly react to compliments heard, they affect them positively and encourages to say compliments to others, and only a small percentage of the respondents do not want to say compliments to others.

It is necessary to mention the fact that communication skills are expressed not only the exchange of verbal information, but also through non-verbal communication. According to Pease (2003), during interpersonal communication process less than 10 percent information is transmitted by words, voice (tone of voice modulation, additional sound) transmits about 30 per cent, and nonverbal signals provide even about 60 percent of information. The structuring of the survey responses revealed three categories: 1) frequent use of non-verbal language in communication; 2) nonverbal language as an expression of feelings; 3) a rare use of non-verbal language. It can be assumed that their non-verbal language is primitive, as most of them are not properly mastered the 
language of the body. Part of the study participants stated that the use of nonverbal language makes it possible to properly express their feelings without using words. The respondents claim that for them verbal communication between them is much more acceptable.

In preparation of social-risk adolescents for transition from school to adult life an important issue is their eating habits. Recently it has been observed that more and more teenagers choose fast food, which does not provide the essential nutrients. It can be assumed that having poor eating habits they transmit them to their children.

From the analysis of answers of the respondents about their eating habits three categories are distinguished: 1) unhealthy eating habits; 2) efforts to eat a healthy food; 3) food as a source of life. It can be argued that the biggest category is first one showing that respondents lack the skills associated with a healthy diet. Most of them not only fail to realize that the body must be equipped with the necessary nutrients but also fail to comply with any nutritional regimen. They don't follow the dietary regimen and don't eat in the morning and overeat in the evenings or even at night and only a small proportion of respondents try to take care of their diet and perceive food as material needed for survival.

From the analysis of essays of social risk teenagers attending day care center on theme „Food Preparation” five categories are distinguished: 1) Food preparation as a hobby; 2) do not wish to cook; 3) put emphasis on the aid for mother during preparation of food; 4) lack of time for cooking; 5) promise to start prepare food in the future. Respondents argue that they are interested in the preparation of food, they love it, but most of them do not prepare food themselves and can only help mother in this. However, neither one of them was not mentioned in an essay that food preparation requires not only produce a certain dish, but also to lay the table properly. Therefore, we can assume that they lack full-fledged cooking skills and are not interested to spend their time cooking, but all brings the promise in the future to begin food preparation.

From the analysis of essays of social risk teenagers attending day care center on the shopping skills three categories are distinguished: 1) Lack of independent shopping skills; 2) purchases o ,unhealthy food”; 3) grocery choice considering the prices. It can be argued that adolescents belonging to a social risk group do not have adequate skills to independent shopping in the store, unable to choose suitable products, so they often use the list of foods drawn by mothers and due to lack of financial resources in their families respondents pay big attention to the price of goods.

The very actual problem for social risk adolescents is saving of money. Most of them do not have adequate skills that enable optimal use of the money. Therefore, it is essential to develop a rational approach to their money and their savings. The structuring of the survey responses revealed five categories: 1) lack of money saving skills; 2) lack of personal money; 3) efforts to save money; 
4) efforts to earn money; 5) the targeted use of the family budget. It can be argued that the respondents don't have money-saving skills. Most of them are not only unable to save money, but also do not realize their value. So often they spend money for entirely unnecessary things, mostly sweets. It can be assumed that the respondents are not able to save money on the fact that they do not have personal finances they can manage. They seek not only save money, but want to try to make money themselves. Since the families of majority of respondents have very modest income, it tries to use the income for a meaningful and purchase only the minimum and most needed. It proves that the family develops money management skills, as the children are learning for targeted use of available funds.

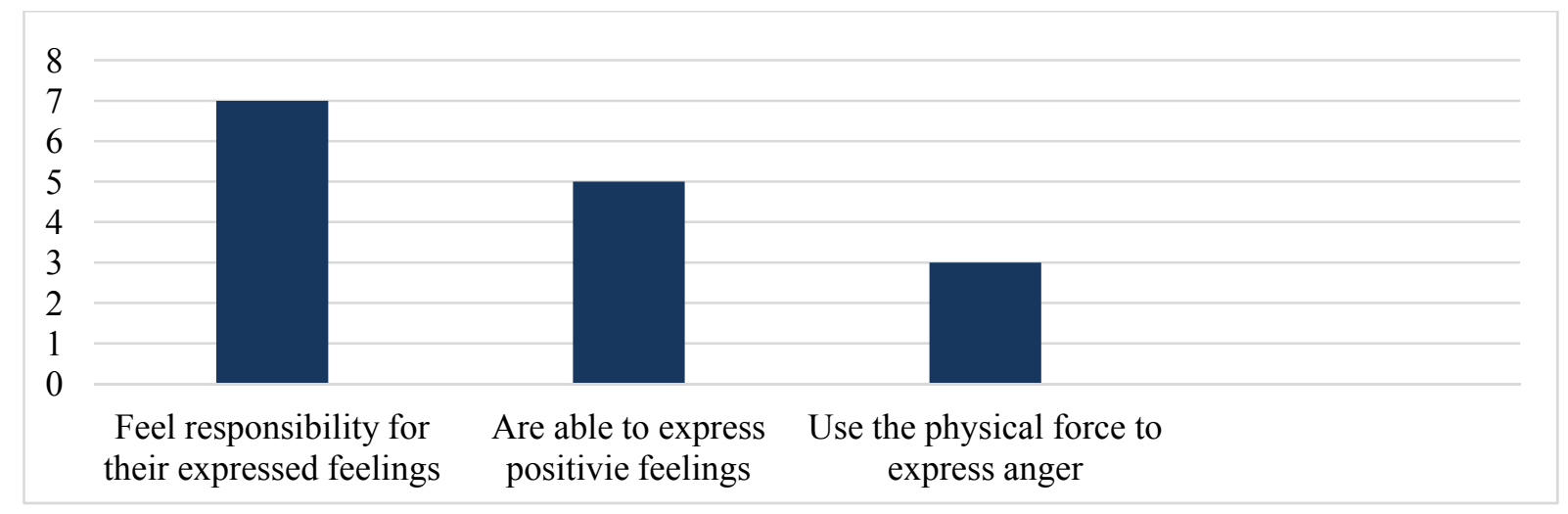

Figure 1.The ability to express feelings and manage anger of adolescents at social risk attending day care centre

The analysis of essays of social risk teenagers attending day care centre on theme „My personal hygiene" made it possible to distinguish the following categories: 1) Recognize the importance of personal hygiene; 2) Dental care as part of personal hygiene; 3) Emphasized the importance of hand washing; 4) Hair and scalp care as part of personal hygiene; 5) Lack of knowledge about personal hygiene skills. It can be argued that teens recognize that personal hygiene is very important and as one of the most important parts of personal hygiene identified by respondents is dental care. Most of them mentioned only that wash the teeth, but it is to be noted that the information about all the peculiarities of oral hygiene available for them is far from the complete. Respondents thought underline the importance of washing hands, hair and head. Only a small proportion of respondents admitted that they lack knowledge about personal. 


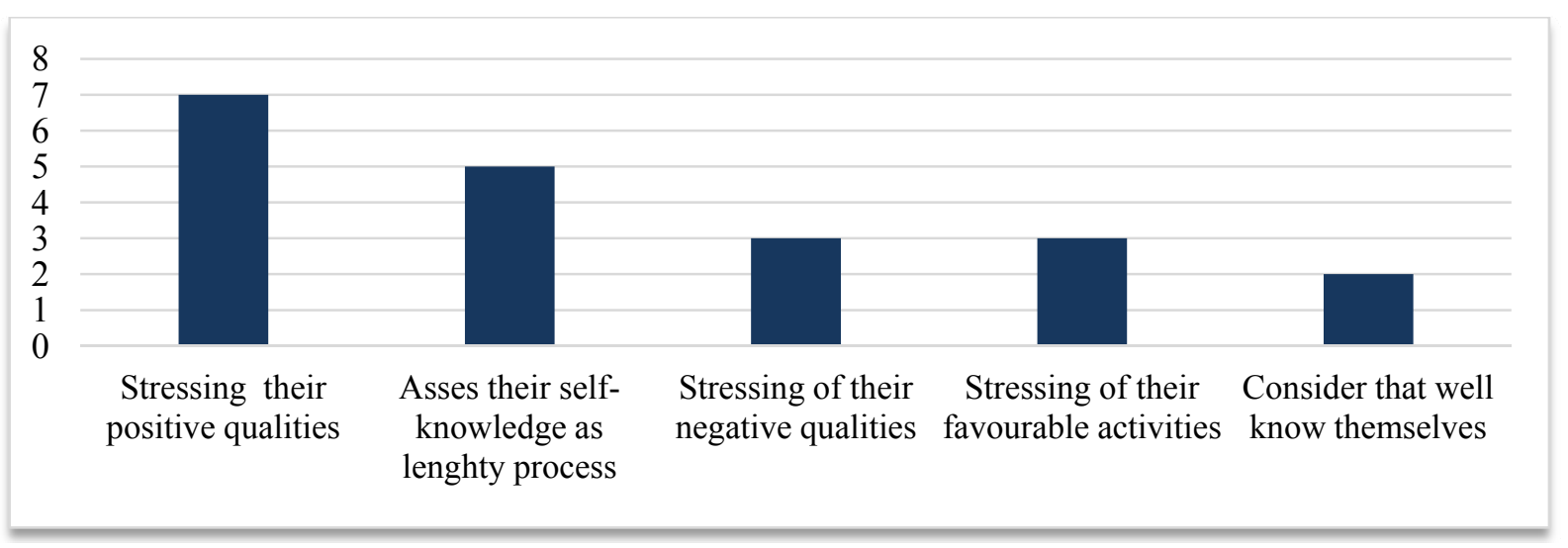

Figure 2. Self-knowledge of social risk teenagers attending day care centre

From the analysis of respondents answers it can be said that stressing positive properties shows that adolescents belonging to a social risk group are able to see positive qualities in themselves, which is the process of selfdiscovery component. Performing the analysis of self-knowledge, respondents identify it as a lengthy process. It is evident that the process of self-knowledge is associated also with negative personal qualities. Social risk adolescents are able to see in themselves not only positive but also negative qualities.

In order to find out how change the expectations of social risk teenagers attending day care center that are bound up with their living conditions, the exercise encouraging to discuss, express their own and hear other session participants' views has been organized. Discussion result reflected in respondents'essays which allowed the identify the following categories: 1) Drug and alcohol related harm and its perception; 2) Emphasis on the impact of the immediate environment; 3) Intimate topics avoidance; 4) The emphasis on spiritual values.

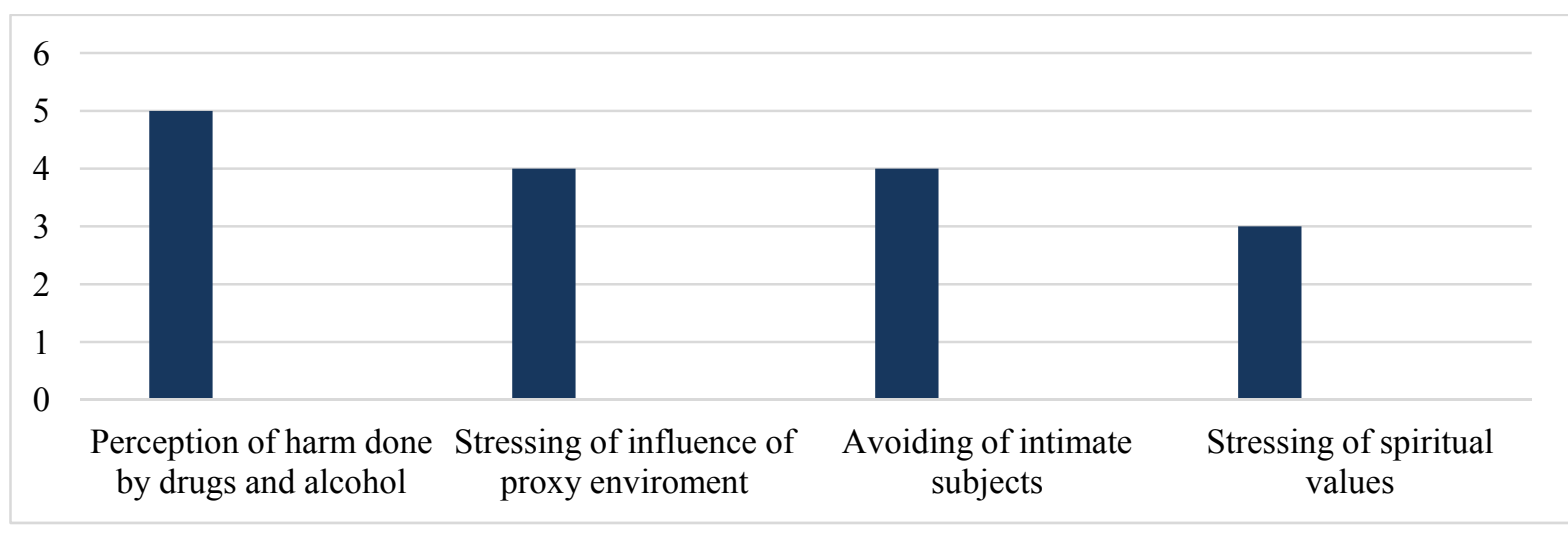

Figure 3. The expectations of social risk teenagers attending day care center, related to living conditions

From respondents thoughts in an essay on could notice that they are aware that alcohol and drugs have adverse effects on the human body. However, these 
answers cannot be assessed unambiguously because often even realizing the damage they are unable to resist the use of psychotropic substances. From assessments of the respondents who identified in their essays the impact of immediate environment to personal socialization it can be assumed that they have a negative experience gained in their immediate environment. Child who has grown up in a socially unhealthy environment generally identify himself with the negative people surrounding him and form the respective image of his „I” (Eskytè, 2008). Social risk teens lack of information about sex education issues. This is what provokes avoidance of intimate topics. However, according to Obelenienè and others (2007), today's AIDS, alcohol, drugs, sex, and similar issues are not only sex education problems, but also show the lack of life meaning issues in school and society.

According Petrylienè and Smilgienè (2012), one of factors contributing to the child's proper conduct is the compliments and awards of parents. Therefore, it was intended to find out how social risk adolescents assess the compliment influence to the communication. Three categories are distinguihed: 1) mphasized importance of a compliments heard; 2) the importance of telling compliments to others; 3) Not willing to say compliments.

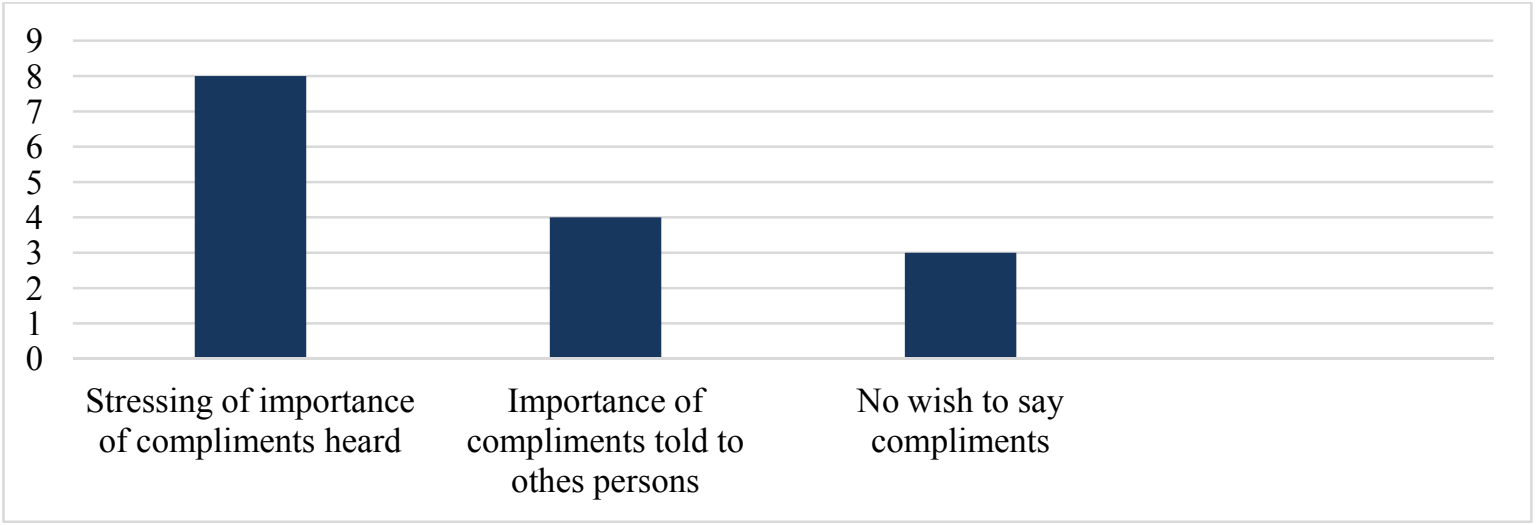

Figure 4. The ability of social risk teenagers attending day care centre to make compliments and respond to them

From the analysis of respondents' essays it can be assumed that compliments are very important for adolescents who have no self-confidence or have little self-confidence, as the positive opinion of others increase their selfesteem, makes it possible not only to rely on their own, but also on others. Respondents emphasize more willingness to say compliments, not just hear them. It is also possible to assume that the reluctance to say compliments toothers is the element of psychological defense of adolescents at social risk.

The structuring of answers of social risk teenagers attending day care centre about non-verbal language identified the following categories: 1) recognized importance of body language; 2 ) body language as an expression of feelings; 3 ) frequent use of negative body language. 


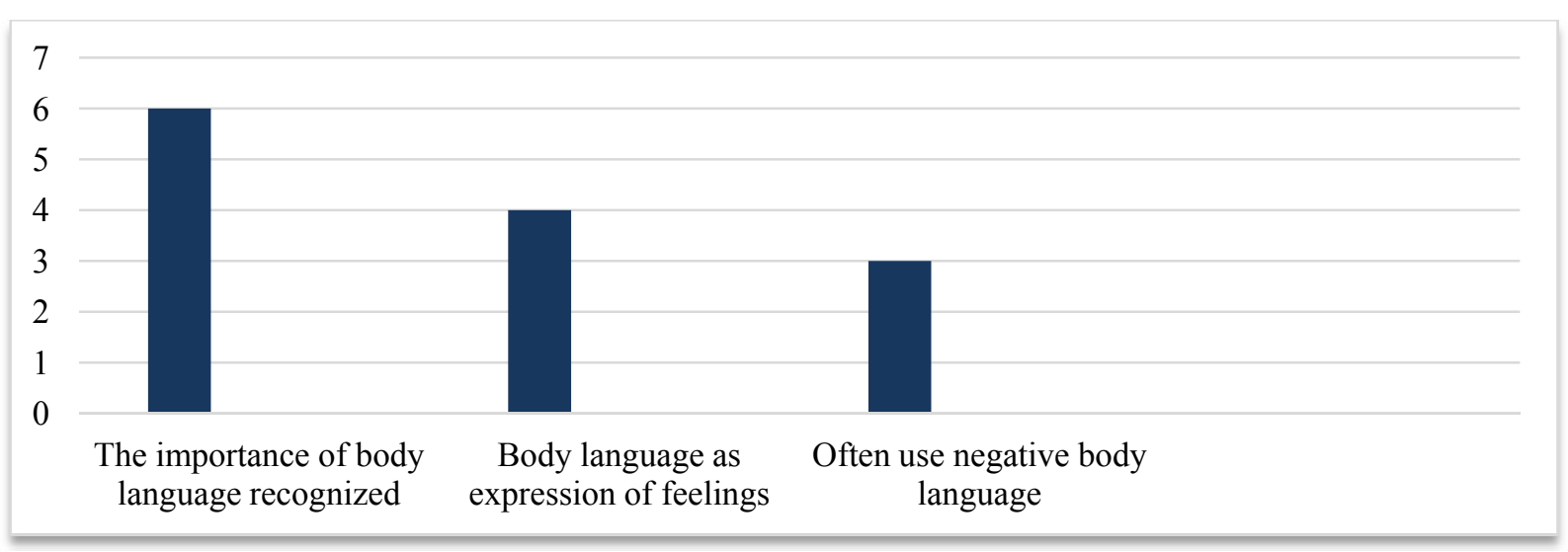

Figure 5. The ability of social risk teenagers attending day care centre to use non-verbal language

From the analysis of the respondents asnwersabout the use of non-verbal language it can be said that adolescents perceive the influence of body language to the communication. This language helps them express positive and negative emotions. Part of the social risk teenagers attending day care center highlight the inability to constructively deal with conflict or emerging problems. Being not able to find appropriate wys for conflict resolution they use negative body language or physical strength.

Frome the analysis of social risk adolescent life skills associated with dietary patterns four categories were identified: 1) efforts to eat a healthy food; 2) the emphasis on useful food nutrients; 3) emphasized importance of breakfast; 4) unhealthy eating habits.

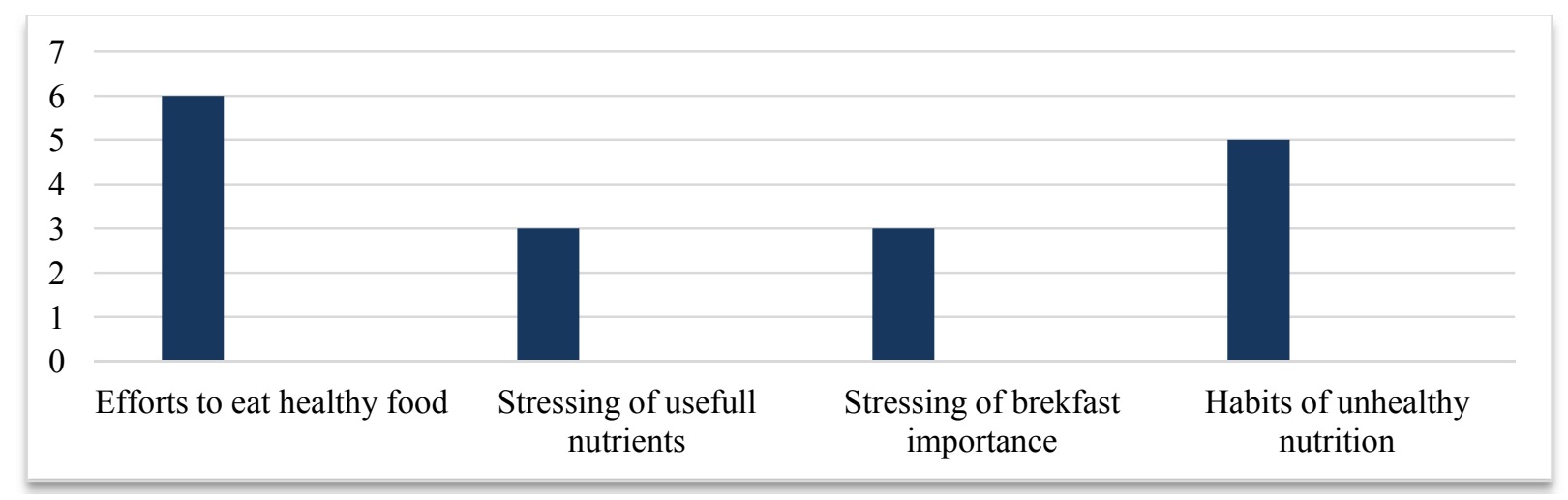

Figure 6. Dietary habits of social risk teenagers attending day care centre

Form the analysis of the answers given by respondents about dietary habits it can be said that the data reflected in essays do not meet the real situation, because before the start of the classes the majority of respondents said that their eating habits were identified as ,unhealthy”. Social risk adolescents perceive the essential nutrients and dietary regimen usefulness for their body, even know that sweets and other ,unhealthy food" are not healthy for the body, but they can not refuse to eat them. 
It is logical that eating habits are associated with cooking skills. Analysis of essay about food preparation allowed to identify the following categories: 1) table serving as part of cooking; 2) compliance with the rules of hygiene in food processing; 3) preparation of simple dishes for dinner; 4) efforts to learn to cook; 5) do not wish to cook.

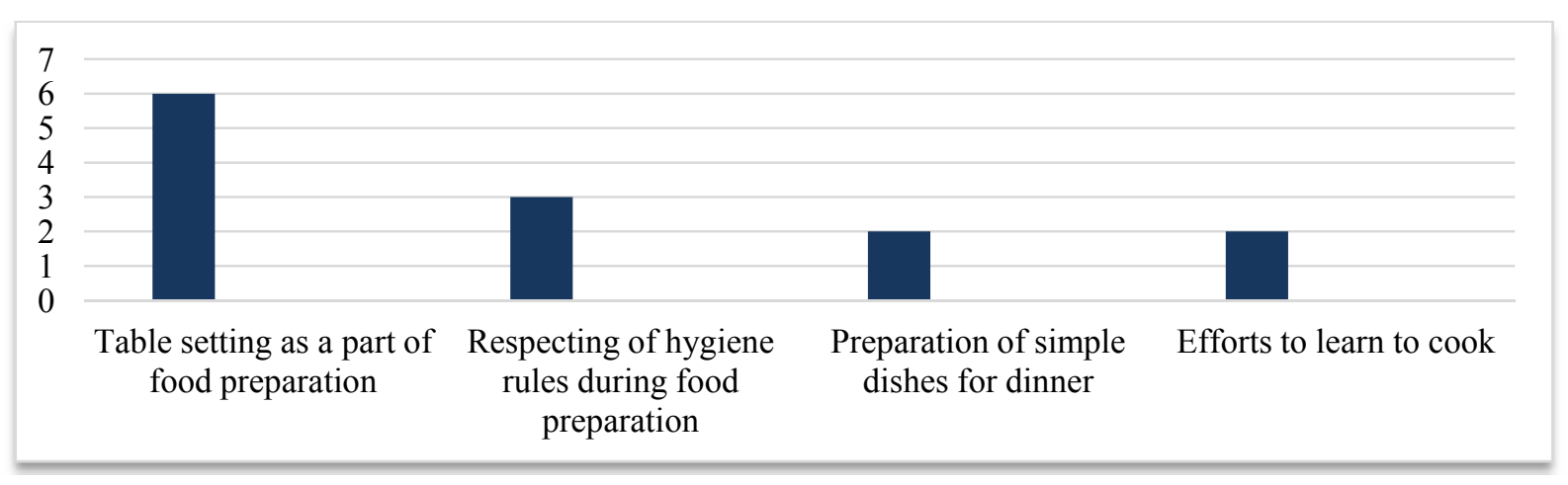

Figure 7. Food preparation skills of social risk teenagers attending day care centre

From the analysis of the survey responses about food preparation skills it can be said that responses reflect the fact that social risk adolescents attending day care centre after the classes were able to assign to food preparation not only cooking, but also table setting. They also are aware of the importance of hygiene in the food preparation and recognize the need to follow a specific nutrition regime.

Some respondents admitted that cooking makes them suffering.

The structuring of the respondents' answers about buying of foods skills identified three categories: 1) Emphasis is placed on usefull advices for shopping; 2) Often buy unnecessary items; 3) Buy taking into account financial opportunities.

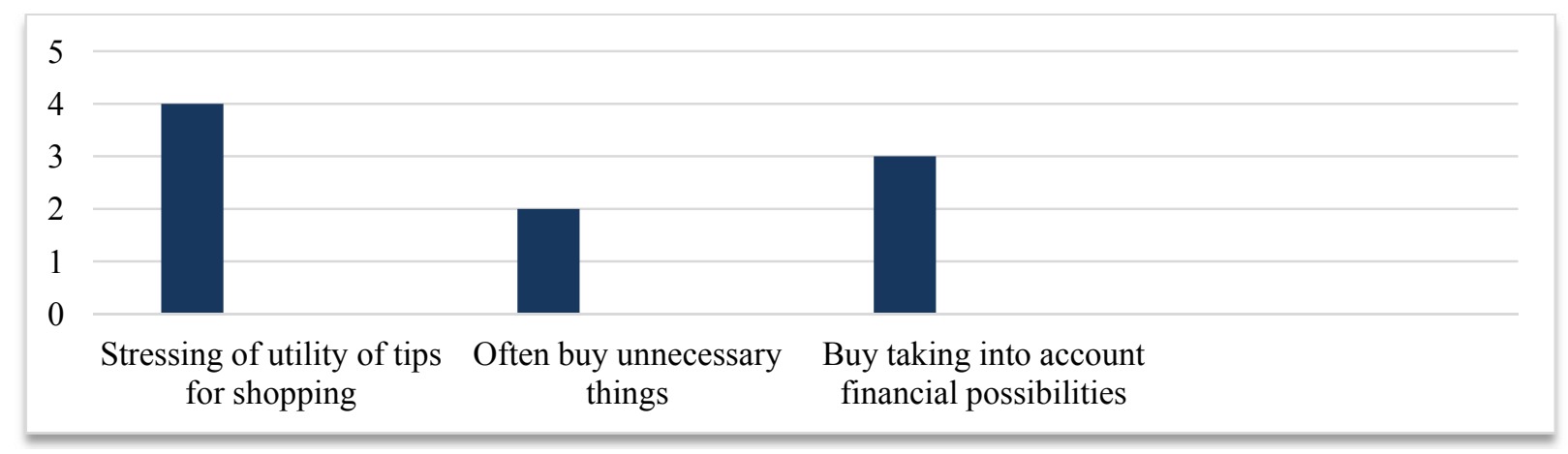

Figure 8. Buying of foods skills of social risk teenagers attending day care centre

From the learners' essays on food procurement skills it can be said that during the workshops social risk adolescents attending day care centre were acquainted with tips that provide information about a rational purchase. Pupils 
recognize the importance of these tips, because they realize that by using rational buying tips it is possible to avoid buying unnecessary items. However, part of young people say that they buy depending on how many they can afford, but they are not able to buy everything they need and note the lack of financial resources.

The rational approach of social risk teens to moneyhas special significance for transition from school age to adult life. From the analysis of the respondents answers about the ability properly use personal finances the following categories were identified: 1) consider before purchasing an item; 2) collects personal funds; 3 ) take into account the family budget; 4) lack of money-saving skills.

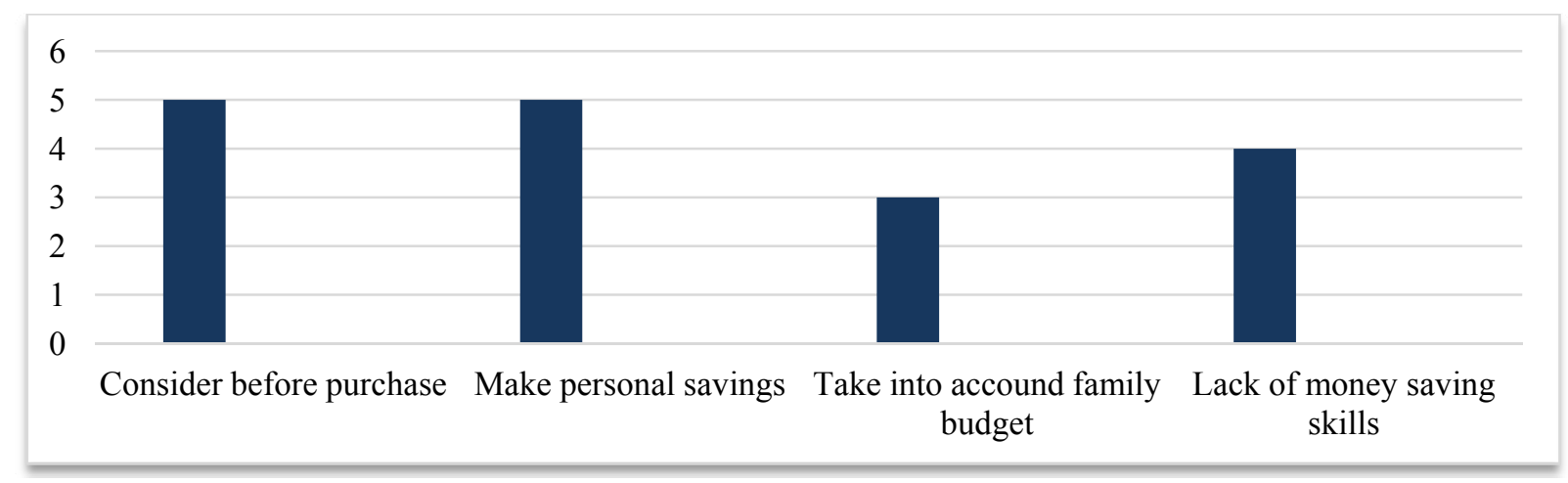

Figure 9. Money management skills of social risk teenagers attending day care centre

After analyzing the answers of the respondents about money management skills it is clear that they reflect the social-risk teen rational approach to finances. They consider before purchasing an item and store personal funds, as well as take into account the family budget. It can be assumed that such an approach was influenced by practical exercises provided. However, social risk adolescents attending day care centre have to deal with money-saving problem. It can be assumed that the inability to save money is influenced by teen parents, who also did not have adequate money-saving skills.

From the analysis of essays of social risk teenagers attending day care center about personal hygiene skills four categories identified: 1) maintenance of clothing and footwear as part of personal hygiene; 2) importance of personal hygiene part; 3) positive influence of mass media; 4) recognize the care of the intimate parts of the body as part of hygiene. 
SOCIETY. INTEGRATION. EDUCATION. Volume III

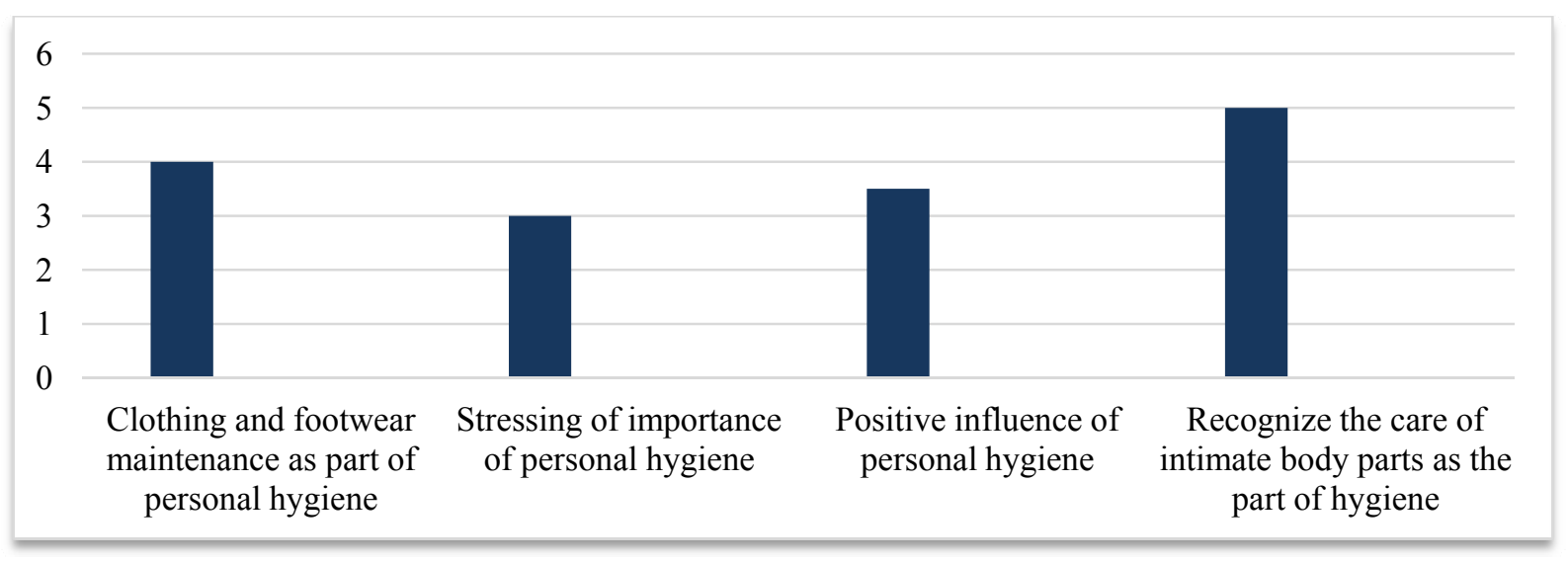

Figure 10. Personal hygiene skills of social risk teenagers attending day care centre

After analyzing the respondents answers about personal hygiene skills it can be said that personal hygiene is extremely important area for the transition from school age to adult life. Learners' essays reflected the emphasis on personal hygiene. According to them, it is essential to take care of their cleanliness. However, most of social risk teenagers attending the day centre as the most important part of personal hygiene distinguish teeth and oral hygiene, hand washing and care of the head and hair cleanliness. Only after the session held on the subject, pupils realized that clothing and footwear maintenance is also part of personal hygiene. Part of the social risk teenagers attending day centre also named the hygiene of intimate parts of the body as part of personal hygiene. It can be assumed that in previous essays this topic has not been touched since the learners did not dare talk about it.

\section{Conclusions}

The scientific literature analysis revealed that it is lack of detailed information about the process of social risk teenagers attending day care centre transition from school age to adult life. However, it can be said that the success of social risk adolescent self-initiation of independent life is significantly influenced by lack of social skills. Social skills are defined as the individual's ability to adapt to the environment and interact with others.

The analysis of the research data highlighted the lack of social skills of social risk teenagers attending day care centre, which hinders the success of the transition from teen school age to adult life process. According to the study, social risk adolescents in day center for most lack self-knolwledge skills. Essay analysis revealed that these teens are unable to eat properly, self-purchase the foods and rationally manage their money.

After apllying of social skills program most obvious change in disadvantaged teenagers attending day care centre is the self-knowledge skill, as in the second part of the essay teenagers were able to identify their positive and negative characteristics as well as favorite activities. It is noted that social risk 
adolescents attending day care centre gained knowledge of healthy nutrition. The second part of the learners' essays emphasize rational grocery buying tips utility. Therefore, it can be said that social risk teens will consider before purchasing certain goods are they necessary. In the essays about personal finance savings social risk adolescents attending day care centre expressed a more rational approach to money, as it has been argued that efforts should be made to save personal funds and consider all the options before purchasing an item. It can be argued that the social skills program has been effective and had an impact on social risk teenagers attending day care center skills enhancement.

\section{References}

Bakutytè, R., Geležinienė, R., Gumuliauskienė, A., Juodraitis, A., Jurevičienė, M., Šapelyė, O. (2013). Socializacijos centro veiklos modeliavimas: ugdytiniu resocializacijos procesu valdymas ir metodika: mokslo studija. Vilnius: BMK leidykla.

Baranauskienè, I., Juodraitis, A. (2008). Neigaliuju profesinè reabilitacija: sékmés prielaidos. Šiauliai: VšI Šiaulių universiteto leidykla.

Bart, L., Schindler, K. H. (2001). Socialinès elgsenos vadovas: ES Leonardo da Vinči programa. Šiauliai: Šiaurès Lietuva.

Brazienè, R., Mikutavičienè, I. (2013). Lietuvos jaunimo perejjimas iš švietimo sistemos i darbo rinką: švietimo, darbo ir užimtumo politikos aspektas. Viešoji politika ir administravimas Nr. 1(12). Kaunas: KTU.

Bronte-Tinkew, J., Brown, B., Carrano, J., Shwalb, R. (2005). Logic models and outcomes for youth in the transition to adulthood. Report to the DC Children and Youth Investment Trust Corporation.

Charles, C., M. (1999). Pedagoginio tyrimo ìvadas. Vilnius: Alma littera.

Erozkan, A. (2013). The effect of communication skills and interpersonal problem solving skills on social self-efficacy. Educational Sciences: Theory \& Practice - 13(2). Prieiga per EBSCO Publishing.

Gailius, Ž., Malinauskas, A., Petkauskas, D., Ragauskas, L. (2013). Darbo su jaunimo grupemis vadovas. Neformaliojo ugdymo praktika Lietuvoje. Vilnius: Firidas.

Griškutė V., Masiliauskienė E., (2010). Vaikų dienos centrų pagalbos socialinès rizikos šeimų vaikams raiška ir jos plètra sąlygojantys veiksniai. Jaunujų mokslininku darbai. Nr. 4 (29).

Hallahan, D., Kauffman, (2003). Ypatingieji mokiniai: specialiojo ugdymo ịvadas. Vilnius: Alma littera.

Jančauskytė, G., Širiakovienė, A., Plaušinaitienė, A. (2013). Vaikų iš socialinès rizikos šeimų socialinių igūdžių plètojimo galimybès dailine veikla vaikų dienos centruose. Socialiniai mokslai 1 (39). Šiauliai: VŠI Šiaulių universiteto leidykla.

Kardelis, K. (2002). Moksliniu tyrimu metodologija ir metodai: (edukologija ir socialiniai mokslai): vadovèlis. Kaunas: Judex.

Kvedaravičiūtè, I. (2007). Nevyriausybinių organizacijų vaidmuo sprendţiant socialinès „gatvès vaikų“ problemas. Academic Journal. Prieiga per: EBSCO Publishing.

Legkauskas, V. (2013). Vaiko ir paauglio psichologija: šiandienos iššūkiai: [vadovèlis aukštuju mokyklu studentams]. Vilnius: Vaga.

Malinauskas R., 2006, Sporto pedagogų ir sportininkų socialinio psichologinio rengimo ypatumai. Monografija. Kaunas: LKKA

Malinauskas, R. (2011). Rizikos grupès vaiku socialiniai igūdžiai : monografija. Kaunas: Lietuvos kūno kultūros akademija. 